\title{
Export dynamics and sales at home
}

\author{
Nicolas Berman \\ Graduate Institute of International Studies \\ Antoine Berthou \\ Banque de France \\ Jérôme Héricourt \\ EQUIPPE - University of Lille I
}

\begin{abstract}
How do firms' sales interact across markets? Are foreign and domestic sales complements or substitutes? Using a large French firm-level database that combine balance-sheet and product-destination-specific export information over the period 1995-2001, we study the interconnections between exports and domestic sales. We identify exogenous shocks that affect firm demand on foreign markets to instrument yearly variations in exports. Our results show that exogenous variations in foreign sales are positively associated with domestic sales, even after controlling for changes in domestic demand. A $10 \%$ exogenous increase in exports generates a 1.5 to $3 \%$ increase in domestic sales in the short-term. This result is robust to various estimation techniques, instruments, controls, and sub-samples. It is also supported by the natural experiment of the Asian crisis in the late 1990's. We discuss various channels that may explain this complementarity.
\end{abstract}

(C) The Authors.

All rights reserved. No part of this paper may be reproduced without the permission of the authors. 


\title{
EXPORT DYNAMICS AND SALES AT HOME*
}

\author{
Nicolas Berman ${ }^{\dagger} \quad$ Antoine Berthou ${ }^{\ddagger} \quad$ Jérôme HÉRICOURT ${ }^{\S}$
}

November 9, 2011

\begin{abstract}
How do firms' sales interact across markets? Are foreign and domestic sales complements or substitutes? Using a large French firm-level database that combine balance-sheet and product-destination-specific export information over the period 1995-2001, we study the interconnections between exports and domestic sales. We identify exogenous shocks that affect firm demand on foreign markets to instrument yearly variations in exports. Our results show that exogenous variations in foreign sales are positively associated with domestic sales, even after controlling for changes in domestic demand. A $10 \%$ exogenous increase in exports generates a 1.5 to $3 \%$ increase in domestic sales in the short-term. This result is robust to various estimation techniques, instruments, controls, and sub-samples. It is also supported by the natural experiment of the Asian crisis in the late 1990's. We discuss various channels that may explain this complementarity.
\end{abstract}

JEL classification: F1, F14, F44, L2

Keywords: Export dynamics, domestic sales, liquidity

${ }^{*}$ We are especially grateful to Richard Baldwin, Matthieu Crozet, Anne-Célia Disdier, Jean Imbs, Linda Tesar, Florian Mayneris, Vincent Vicard and participants at several seminars and conferences for very useful comments and discussions. This research does not reflect the views of the Banque de France.

${ }^{\dagger}$ Graduate Institute of International and Development Studies (IHEID). Address: Case Postale 136, CH 1211, Geneva 21 - Switzerland. Tel: (0041) 22908 5935. E-mail: nicolas.berman@graduateinstitute.ch.

†Banque de France. Address: 39 rue Croix des Petits Champs 75001 Paris - France. Tel: (0033) 01429228 76. E-mail: antoine.berthou@banque-france.fr

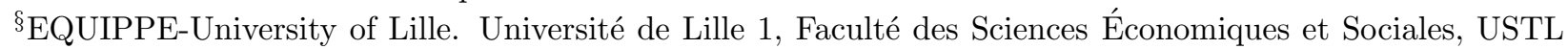
- Cité Scientifique - Bât SH2, 59655 Villeneuve d'Ascq Cedex - France. Tel/Fax: (33) 1440782 78, Email: jerome.hericourt@univ-lille1.fr 


\section{Introduction}

The sales of a firm are distributed across several markets, each of these markets being identified by a specific location and a particular product. Empirical evidence shows that large, productive firms explore more markets and have larger average sales. How sales between these different markets interplay, beyond the simple correlation of market-specific shocks, remains however unclear, though it may be an important determinant of firm-level dynamics. More generally, the interconnections between sales across markets have important implications for the transmission of foreign demand shocks, exchange rate movements or trade policies to the domestic economy.

This paper provides an empirical investigation of this question through the lens of the relationship between French firms' domestic sales and exports. As sales decisions across markets are likely to be simultaneously determined, we develop a strategy that identifies variations in the foreign demand addressed to the firms to predict exogenous changes in exports, and their effect on the firms' domestic sales. The different dimensions of our data allows us to construct instruments that capture the demand specifically addressed to a given firm in the foreign markets (destinations and products) it serves, while controlling for the conditions it faces in the domestic market.

Our empirical analysis relies on a large firm-level dataset containing both firm-level trade data from the French Customs and balance-sheet information over the period 1995-2001, at a yearly frequency. In particular, the balance-sheet data contains domestic and foreign turnovers, our main variables of interest. The customs data contains firm-level exports and imports by product and destination. This information is used together with import data at the productdestination level to construct the demand addressed to firms in both foreign and domestic markets. Our baseline instrument is the sum of imports in the product-destination served by the firms, weighted by the average share of each product-destination in the firm's total exports. ${ }^{1}$ Our results are robust to the use of alternative instruments, including firm-specific tariff changes, or exposure to large foreign shocks, such as financial crises or civil wars.

We find that a $10 \%$ exogenous increase in exports generates a 1.5 to $3 \%$ increase in domestic sales in the short-term, depending on the specification. This complementarity is robust to various estimation techniques, combinations of instruments, sub-samples, and inclusions of additional controls. These variations in domestic sales are related to both factor accumulation

\footnotetext{
${ }^{1}$ A product is defined at the HS6 level.
} 
and changes in total factor productivity. Our results are valid in cases where the foreign demand for firms' products is either increasing or decreasing, the effect being slightly larger in the latter case. Finally, the complementarity is observed across all firm sizes, but it is relatively more pronounced for smaller firms.

Why are firms' domestic sales positively related to exogenous changes in exports? In most international trade models (e.g. Melitz, 2003), domestic and foreign sales are only related through idiosyncratic productivity. Consequently, exogenous shocks affecting a given location have no effect on sales in other markets. However, several theoretical mechanisms can be used to rationalize the existence of linkages between exports and domestic sales. On the one hand, increasing exports sales may well come at the expense of domestic sales in the short run in the presence of capacity constraints. On the other hand, at least two mechanisms would predict complementarity: the short-run liquidity channel, whereby the cash flow generated by exports is used to finance domestic operations in the short-term (to pay suppliers, hire workers or invest), and the existence of increasing returns.

Our results do not exclude the possibility of capacity constraints in the short-term, but simply suggest that they do not dominate once export sales are properly instrumented. While the main objective of this paper is not to provide a definitive answer to the mechanism underlying our findings, we provide a number of results supporting the liquidity channel. In particular, we find that firms belonging to sectors in which the need for short-term liquidity is higher - due to higher working capital requirement - have domestic sales that exhibit a significantly larger response to exogenous variations in exports.

Our results have direct consequences for the effect of international trade on the synchronization of international business cycles. Common wisdom generally attributes the strong correlation between openness and the synchronization of business cycles ${ }^{2}$ to a simple mechanism: as economies become more open, exports and imports represent a larger share of firms' total sales or input purchases. This makes firms more sensitive to variations in foreign demand, which tends to propagate shocks. Our results imply that foreign business cycles may be transmitted indirectly to domestic markets through the complementarity between firms' domestic and foreign sales.

\footnotetext{
${ }^{2}$ Theoretically, the fact that international trade causes tighter business cycle synchronization is ambiguous. If trade openness leads to greater specialization, and cycles are predominantly sector-specific, trade openness may actually decrease business cycle correlation. However, empirical works have found strong evidence that trade openness amplifies international business cycles correlation. See, among many others, Frankel and Rose (1998) or Baxter and Kouparitsas (2005).
} 
Beyond business cycles correlation, these results have many implications regarding the transmission of foreign trade policy, exchange rate shocks or financial crises to the domestic economy. In the case of the 1997-98 Asian crisis, we indeed show that firms that were more exposed to the destinations that experienced the crisis suffered a larger drop in domestic sales during the event. More generally, our results support the idea that changes in exports in one market, due to changes in market-specific demand conditions, tend to affect sales in other markets in the same direction. This transmission of firm performance across markets is not explained by business cycles' synchronization.

A very recent, yet flourishing, body of literature has emphasized the role of capacity constraints in explaining how exports affect the volatility of firms' sales, pricing strategies, or export modes (Vannoorenberghe, 2011, Soderby, 2011, Nguyen and Schaur, 2011, Blum et al., 2011). ${ }^{3}$ The general idea of these papers is that if firms face convex costs in the short-run, they may substitute sales away from a given market when growth opportunities appear in other markets. The fact that firms' exports (or export status) are negatively correlated with their domestic sales appears to support this idea. Our results show that a change in exports, when predicted by exogenous demand conditions in foreign markets, triggers a change in domestic sales in the same direction. At the end of this paper, we show that, indeed, capacity constraints seem to influence this relationship, but they are not strong enough to offset the complementarity between sales across markets.

Finally, a number of recent empirical papers have tested the influence of foreign macroeconomic shocks on firms' activities through factor utilization and productivity. Of particular interest are the papers by Ekholm et al. (2011) and Hummels et al. (2010). Ekholm et al. (2011) showed that for Norway, firms that were more exposed to the appreciation of the Krona in the early 2000's (through higher competitive pressure at home or reduced competitiveness on foreign markets) restructured more. Hummels et al. (2010) showed that for Denmark, positive export shocks lead to an expansion of firms' employment and wages paid to all types of workers. Our results suggest that these gains are not only directly related to foreign shocks, but may also be the indirect consequence of the complementarity between export and domestic sales. ${ }^{4}$

\footnotetext{
${ }^{3}$ This recent literature follows a more ancient research documenting the relationship between exports and domestic production at the country level (Ball et al., 1966, Dunlevy, 1980; Haynes and Stone, 1983; Zilberfarb, 1980). Most of these papers tested the "capacity pressure" hypothesis, using aggregate data, and produced mixed results.

${ }^{4}$ To a lesser extent, our paper also contributes to the vast literature interested in the effect of international
} 
The next section presents the data and some descriptive statistics. Section 3 presents our empirical methodology. Section 4 reports our baseline results, a number of robustness checks, and an application of our results to the Asian crisis from 1997-98. We discuss various potential channels of transmission in section 5. The last section concludes.

\section{Data and stylized facts}

\subsection{Database}

Our empirical analysis relies on two main datasets that report information at the firm level.

The first source is the balance sheet dataset BRN (Bénéfice Réels Normaux), which relies on fiscal declarations by domestic French firms. The BRN database is constructed from mandatory reports of French firms to the tax administration, which are in turn transmitted to INSEE (the French Statistical Institute). This dataset reports information including firms' total turnover and export turnover, employment, capital stock, value added, the industry, year, and balancesheet variables. The data covers the period 1995-2001, for which we have information on both the total turnover and export turnover. This combined information is used to compute domestic turnover. The BRN contains between 650,000 and 750,000 firms per year over the period, which is around $60 \%$ of the total number of French firms. Importantly, this dataset is composed of both small and large firms, since no threshold applies. Eaton et al. (2004) and Eaton et al. (2011) provide a more detailed description of the database. Because we are interested in the relationship between export flows and domestic sales, we only keep firms that export at least once over the period 1995-2001. We also restrict our analysis to firms whose primary activity is manufacturing. This is in particular to exclude wholesalers. Finally, we clean the data by dropping the firms that have a share of exports over total sales above $90 \%^{5}$, and the top and bottom percentile in terms of total average turnover growth.

trade on firm performance, which has been a major area of research since the late 1990's. Most papers focused on the link between exporting and productivity at the firm level, showing that the most productive firms selfselect on export markets. They provide only mixed evidence on the productivity gains generated by entry into foreign markets, however (early works include Bernard and Jensen, 1999 or Bernard and Wagner, 1998; for recent contributions see De Loecker, 2007, Van Biesebroeck, 2005, Park et al., 2009). These results have led many authors to argue that trade liberalization may affect economic growth mainly through the process of resource reallocation across firms within sector, with little contribution of productivity gains within firms. Our results suggest that export performance may affect domestic performance in the short-term, either through factor accumulation or TFP gains.

${ }^{5}$ This drops firms located in France whose main activity is to sell goods abroad. Less than $1.8 \%$ of the observations are dropped. Note that our results are robust to the use of the full sample. 
The second source of data used in this paper corresponds to the French customs data, which reports exports flows with firm, destination and product dimensions. Both the quantity (in tons) and value of each flow are reported. The product classification system is the European Union Combined Nomenclature at 8 digits (CN8). The customs database is virtually exhaustive. After merging the two sources, we are left with between 90 and $95 \%$ of French exports contained in the customs data, depending on the year.

Our strategy relies on the estimation of the effect of export sales on domestic sales. We use the geographical structure of exports for each firm to compute firm-specific (by destination and by product) measures of world demand for the goods produced by the firm, focusing on either all products exported by the firm or on its main exported product by destination. We will use these variables as instruments for export sales in our empirical analysis. Their construction is further detailed in the next section.

\subsection{Descriptive statistics}

This section provides some descriptive statistics about the characteristics of the firms contained in our sample. Our final sample is composed of 29,542 firms exporting at least once over the period 1995-2001. On average, around 21,000 firms report exports each year. Table 1 reports information for these firms regarding their number of employees, their domestic sales (in thousands of euros), their export sales (in thousands of euros), export propensity, which is measured as the ratio of export turnover over total turnover, and the log change of exports and domestic sales. The size of the firms contained in the data is very heterogeneous: it starts with a single employee for the smallest firm, whereas the largest has almost 82,000 employees.

Table 1: Descriptive statistics: firm size, sales and export propensity

\begin{tabular}{lccccc}
\hline \hline & Mean & $1^{\text {st }}$ Quartile & Median & $3^{\text {rd }}$ Quartile & S.D. \\
\hline Number of employees & 114.9 & 12.0 & 32.0 & 76.0 & 619.4 \\
Domestic sales & $1.1 \mathrm{e}+05$ & 7375.0 & 19442.6 & 55133.2 & $8.9 \mathrm{e}+05$ \\
Export Sales & 57520.2 & 632.0 & 2794.0 & 13291.0 & $9.3 \mathrm{e}+05$ \\
Propensity to export & 0.22 & 0.04 & 0.13 & 0.33 & 0.22 \\
$\Delta$ ln Domestic sales & 0.03 & -0.07 & 0.03 & 0.14 & 0.27 \\
$\Delta$ ln Export Sales & 0.06 & -0.21 & 0.04 & 0.31 & 0.90 \\
\hline \hline
\end{tabular}

Note: Source: authors' computation from BRN data. Export and domestic turnover are expressed in thousands of euros. Propensity to export corresponds to exports/total sales. 
Export propensity has a minimum that is close to zero, whereas the most internationalized firm in our sample has export sales that are close to the volume of total sales. The distribution of export export propensity confirms that most of firms' sales correspond to business operations on the domestic market: $50 \%$ of firms in the sample export $14 \%$ or less of their total turnover; $75 \%$ of firms export at most a third of their total turnover. Hence, this empirical pattern confirms that firms' sales are mostly concentrated on the domestic market, whereas exports are concentrated on a small number of firms that have a large degree of internationalization. Finally, both export and domestic sales exhibit, on average, a positive growth (3 and $4 \%$ respectively), with foreign sales being significantly more volatile than domestic sales.

Table 2: Export propensity by firm-size class

\begin{tabular}{lc}
\hline \hline Size class & $\begin{array}{c}\text { Mean export } \\
\text { Propensity }\end{array}$ \\
\hline$<20$ employees & 0.21 \\
$20-50$ employees & 0.19 \\
$50-100$ employees & 0.22 \\
$100-200$ employees & 0.25 \\
$200-500$ employees & 0.29 \\
$>500$ employees & 0.33 \\
All categories & $\mathbf{0 . 2 2}$ \\
\hline \hline
\end{tabular}

Source: authors' computation from BRN data. Export propensity corresponds to exports/total sales.

We then provide simple descriptive evidence regarding the relationship between firms' size and export propensity. Using the number of employees, six classes of firms' size are defined in Table 2. For each category, we report the average export propensity. Overall, these mean values are larger than the median presented in the previous table. However, the numbers that are displayed confirm that larger firms have a higher export propensity. On average, firms with 500 or more employees export a third of their total turnover, whereas small firms export around $21 \%$ of their total turnover. 


\section{Empirical methodology}

Endogeneity issues. Our main objective is to identify the effect of changes in export sales on domestic sales. In general, we want to estimate a specification taking the following form:

$$
\ln Y_{i t}=\alpha+\beta \ln X_{i t}+\mu_{i}+\lambda_{k t}+\varepsilon_{i t}
$$

where $X_{i t}$ and $Y_{i t}$ are respectively the exports and domestic sales of firm $i$ during year t. $\mu_{i}$ denotes firm-specific unobserved characteristics, and $\lambda_{k t}$ represents sector $\times$ year dummies. ${ }^{6}$ The latter captures in particular business cycle conditions and changes in input prices. Our coefficient of interest is $\beta$, the coefficient on export sales $X_{i t}$ : a negative sign would imply substitutability between export and domestic sales, while a positive sign would suggest complementarity.

Endogeneity is obviously a major concern in this specification. Domestic sales and exports are likely to be jointly determined by the same aggregate or idiosyncratic shocks affecting the demand addressed to the firm. For instance, a productivity shock is expected to simultaneously raise domestic and foreign sales of the firm, thus introducing a positive bias in the relationship between the two variables. In general, domestic and foreign sales are determined by macroeconomic conditions on each market, which are likely to be correlated. The different dimensions of our data allow us to build instruments capturing the demand specifically addressed to a firm in the foreign markets it serves, while controlling for the demand it faces in the domestic market. To do so, we make use of the information provided by the French customs on the range of products and destinations served by each firm.

Instruments. Our main instrument is constructed using information about the foreign demand addressed to the firm using product and destination information. Specifically, we compute the sum of foreign imports in the product-destination served by the firm in year $t$, weighted by the average share of each product-destination in the firm's total exports over the period. Weights are computed using the average share of the product-destination in the firm's total exports over the 1995-2001 period. A product is defined at the 6-digit (HS6) level. More precisely, we define:

$$
F D_{i t}=\sum_{j, p} \omega_{i j p} M_{j p, t}
$$

\footnotetext{
${ }^{6} \mathrm{~A}$ sector is defined at the 2 digit (NES classification, 36 sectors) level.
} 
where $\omega_{i j p}$ is the average share of each product $p$ and destination $j$ in firm $i$ 's exports over the period. This variable is expected to impact the firm's exports, but not domestic sales, unless foreign demand for the firm's products is correlated with the domestic demand of these products. To ensure that our results are not driven by this international business cycle correlation, we explicitly control in our baseline specification for the domestic equivalent of our instrument. It is defined as the domestic demand addressed to the firm $\left(D D_{i t}\right)$. This mirror variable is the sum of the world imports from France for all products exported by firm $i$, weighted by the share of each product in the firm's exports:

$$
D D_{i t}=\sum_{j, p} \omega_{i j p} M_{F R, p, t}
$$

Therefore, this variable provides a firm-specific measure of domestic demand addressed to the firm. Alternatively, we compute the foreign demand and domestic demand variables using sales for the "core" product of the firm on each destination: $F D_{i t}^{\text {core }}$ and $D D_{i t}^{\text {core }}$, respectively. The core product of the firm is defined at the HS4-digit level as the product with the highest value of export over the entire period. The detailed computation of these variables is provided in the data appendix.

Baseline specification. We include $D D_{i t}$ explicitly in equation (1). The following equation assesses the effect of exogenous changes in exports (through variations in $F D_{i t}$ ) on domestic sales, controlling for domestic demand:

$$
\ln Y_{i t}=\alpha+\beta \ln X_{i t}+\delta D D_{i t}+\mu_{i}+\lambda_{k t}+\varepsilon_{i t}
$$

where we expect $\delta$ to be positive. We estimate this specification by two-stage-least-squares (2SLS). Note that our results are unchanged when the two-way relationship between export and domestic sales is jointly estimated using 3SLS, allowing for residual correlation across equations. ${ }^{7}$ Finally, in all estimations, standard errors are robust to heteroscedasticity and clustered at the sectoral level (based on NACE 36 industry classification) using Froot (1989) correction.

Alternative instruments. Testing for overidentifying restrictions requires at least two instruments, as we have one endogenous regressor. To assess the exogeneity of our baseline

\footnotetext{
${ }^{7}$ Results are available upon request.
} 
instruments, and to show that our results are unchanged when using other measures of foreign demand, we constructed a number of alternative instruments. The first is a measure of firmspecific tariffs faced by French exporters, which depend on the destinations and products they export. It is constructed essentially in the same way as $D D_{i t}$ above, but using tariffs instead of imports. Tariffs are arguably more exogenous because they are less correlated with domestic conditions. However, this instrument is weaker as tariff variations are limited over the period. Second, we will make use of the occurrence of large (negative) shocks, such as civil wars or the 1997-98 Asian crisis, to show that our results hold whatever the source of variations in foreign demand. More details about the computations of these variables are provided later in the paper, as well as in the data appendix.

Using these alternative instruments allows us to perform Hansen's J-test of overidentifying restrictions. Insignificant test statistics indicate that the orthogonality of the instruments and the error term cannot be rejected; thus, our choice of instruments is appropriate on that ground. As shown later, the overidentifying restrictions cannot be rejected. Finally, we performed the Durbin-Wu-Hausman test for exogeneity of regressors. Unsurprisingly, the null hypothesis of exogeneity is rejected in most cases. ${ }^{8}$ This clearly shows that we need to use IV methodologies to identify exogenous variations of exports.

In all estimations, we report the F-stat form of the Kleibergen-Paap statistic, the heteroskedastic and clustering robust version of the Cragg-Donald statistic suggested by Stock and Yogo (2005) as a test for weak instruments. Most statistics are comfortably above the critical values, confirming that our instruments are strong predictors of export sales.

\section{Main Results}

\subsection{Baseline regressions}

Within estimations. We start with a simple estimation of Equation (4) by OLS where the firms' domestic sales are explained by export sales and a set of controls for the domestic market conditions, firm fixed effects and year dummies (alternatively with sector $\times$ year dummies). This specification offers a benchmark estimation of the relationship between domestic and foreign sales, which can be compared to our preferred estimations (presented in the following

\footnotetext{
${ }^{8}$ Detailed results of these tests available upon request.
} 
tables) where export sales are instrumented by foreign market demand.

Table 3: Export and domestic sales: correlation

\begin{tabular}{|c|c|c|c|c|}
\hline & $(1)$ & $(2)$ &  & $(4)$ \\
\hline Dep. Var. & ln Dom. sales & \multicolumn{3}{|c|}{$\Delta \ln$ Dom. sales } \\
\hline ln Export sales $i t$ & $\begin{array}{c}0.006 \\
(0.005)\end{array}$ & & & \\
\hline ln Domestic demand $i t$ & $\begin{array}{c}0.139^{a} \\
(0.025)\end{array}$ & & & \\
\hline ln Number of firms $k t$ & $\begin{array}{c}0.374^{a} \\
(0.119)\end{array}$ & & & \\
\hline ln Industry domestic sales $k t$ & $\begin{array}{c}0.134^{b} \\
(0.051)\end{array}$ & & & \\
\hline$\Delta \ln$ Export sales $_{i t}$ & & $\begin{array}{c}-0.012^{a} \\
(0.003)\end{array}$ & $\begin{array}{c}-0.017^{a} \\
(0.003)\end{array}$ & $\begin{array}{c}-0.018^{a} \\
(0.003)\end{array}$ \\
\hline$\Delta \ln$ Domestic demand $_{i t}$ & & $\begin{array}{c}0.125^{a} \\
(0.019)\end{array}$ & $\begin{array}{l}0.123^{a} \\
(0.027)\end{array}$ & $\begin{array}{c}0.107^{a} \\
(0.026)\end{array}$ \\
\hline$\Delta \ln$ Number of firms $k t$ & & $\begin{array}{c}0.164^{c} \\
(0.088)\end{array}$ & $\begin{array}{l}-0.084 \\
(0.068)\end{array}$ & \\
\hline$\Delta$ ln Industry domestic sales $k t$ & & $\begin{array}{c}0.076^{a} \\
(0.026)\end{array}$ & $\begin{array}{c}0.056^{a} \\
(0.020)\end{array}$ & \\
\hline Observations & 110721 & 110721 & 110721 & 110721 \\
\hline Firm FE & Yes & No & Yes & Yes \\
\hline Year dummies & Yes & Yes & Yes & No \\
\hline Sector $\times$ year dummies & No & No & No & Yes \\
\hline
\end{tabular}

Robust Standard errors, clustered by NACE 36 industry, in parentheses. ${ }^{c}$ significant at $10 \% ;^{b}$ significant at $5 \% ;{ }^{a}$ significant at $1 \%$.

Table 3 presents the results of the estimation in levels (column 1) and in first differences (columns 2 to 4). Domestic market conditions are controlled for by using a measure of the domestic demand addressed to the firm (ln Domestic demand ${ }_{i t}$ as defined by (3)), the number of firms that operate in the same industry (ln Number of firms ${ }_{k t}$ ) and the industry domestic sales (ln Industry domestic sales $k t$ ). The results show that the relationship between domestic and foreign sales is either insignificant or negative. In other words, controlling for demand conditions on the domestic market, an increase of exports reduces domestic sales. ${ }^{9}$ Moreover,

\footnotetext{
${ }^{9}$ This result is in line with Vannoorenberghe (2011) who also finds that domestic sales growth is negatively correlated with export sales growth.
} 
variations of the domestic demand for products in which the firm is specialized are positively related to the firm's domestic sales. The effect of the number of domestic firms operating in the same industry is positive when significant, as the effect of industry domestic sales.

While this estimation provides an interesting correlation between the two variables, it however does not allow us to infer anything about the causal effect of an exogenous change in exports on domestic sales. In the rest of the paper, we shall use the aforementioned instruments to estimate the effect of an exogenous change in exports on domestic sales, originated by a variation of foreign demand.

Instrumental variables estimations. We present in Table 4 the results of the 2SLS estimations, in which foreign sales are instrumented by measures of foreign demand addressed to the firm. In the first two columns, all variables are expressed in levels and export sales are instrumented using foreign demand in HS6 products exported by the firm $\left(F D_{i t}\right.$, as defined in equation (2)). The estimations control for the domestic demand addressed to the firm. Column (1) includes year dummies and controls for additional variables that identify sector-specific domestic business cycle: the industry domestic sales and the number of domestic firms operating in the same industry. In column (2), our preferred specification, sector $\times$ year dummies are included. Column (3) uses the foreign demand for the core (HS4) product exported by the firm ( $F D_{i t}^{\text {core }}$ as defined above) as the instrument for exports.

The estimation results contrast with those presented in the previous table, where exports were not instrumented by exogenous changes in the foreign demand addressed to the firms. The 2SLS estimations in levels conclude to a positive and highly significant relationship between exports and domestic sales: an increase in a firm's exports, induced by an increase of the foreign demand, raises domestic sales in the same year. This result is stable when the demand for the core product is used as an alternative instrument for the export sales (column 3) and when sector $\times$ year dummies are introduced (column 2). The strength of our instruments is confirmed by the Kleibergen-Paap statistics, which are above the critical values.

The difference between the estimation results presented in Tables 3 and 4 might reflect that firms set their capacity and determine their production ex-ante after anticipating a certain level of aggregate demand. This introduces substitutability between domestic and foreign sales, and generates a downward bias in the export sales coefficient in OLS estimations. Instrumenting export by exogenous changes in foreign demand, together with controlling for domestic demand 
Table 4: Baseline results

\begin{tabular}{|c|c|c|c|c|c|}
\hline Estimator & (1) & $\overline{(2)}$ & $\begin{array}{c}(3) \\
\text { 2SLS }\end{array}$ & $(4)$ & 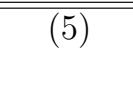 \\
\hline Dep. Var. & \multicolumn{3}{|c|}{ ln dom. sales } & \multicolumn{2}{|c|}{$\Delta \ln$ dom. sales } \\
\hline ln Export sales $i t$ & $\begin{array}{c}0.146^{a} \\
(0.033)\end{array}$ & $\begin{array}{c}0.158^{a} \\
(0.029)\end{array}$ & $\begin{array}{c}0.239^{a} \\
(0.041)\end{array}$ & & \\
\hline ln Domestic demand $i t$ & $\begin{array}{l}0.099^{a} \\
(0.023)\end{array}$ & $\begin{array}{l}0.105^{a} \\
(0.021)\end{array}$ & & & \\
\hline ln Number of firms $k t$ & $\begin{array}{l}0.315^{a} \\
(0.083)\end{array}$ & & & & \\
\hline ln Industry domestic sales $k t$ & $\begin{array}{l}0.122^{a} \\
(0.046)\end{array}$ & & & & \\
\hline ln Dom. demand core prod.it & & & $\begin{array}{l}0.084^{a} \\
(0.018)\end{array}$ & & \\
\hline$\Delta \ln$ Export sales $_{i t}$ & & & & $\begin{array}{l}0.232^{a} \\
(0.048)\end{array}$ & $\begin{array}{l}0.341^{a} \\
(0.089)\end{array}$ \\
\hline$\Delta \ln$ Domestic demand $_{i t}$ & & & & $\begin{array}{c}0.084^{a} \\
(0.013)\end{array}$ & $\begin{array}{l}0.073^{a} \\
(0.014)\end{array}$ \\
\hline Observations & 146702 & 146702 & 146702 & 110721 & 105135 \\
\hline Firm FE & Yes & Yes & Yes & No & Yes \\
\hline Year dummies & Yes & No & No & No & No \\
\hline Sector $\times$ year dummies & No & Yes & Yes & Yes & Yes \\
\hline Kleibergen-Paap stat. & 95.1 & 94.8 & 47.3 & 36.2 & 14.1 \\
\hline
\end{tabular}

Robust Standard errors, clustered by NACE 36 industry, in parentheses. ${ }^{c}$ significant at $10 \% ;^{b}$ significant at $5 \%$; ${ }^{a}$ significant at $1 \%$. All estimations but (3) (first differences) include firm fixed effects. The critical value for the weak instruments test is based on a $10 \% 2 \mathrm{SLS}$ bias at the $5 \%$ significance level, which is 16.4 is all estimations. The instruments are the following. In columns (1), (2), (4), (5): foreign demand in HS6 products exported by the firm $\left(F D_{i t}\right.$ in the main text) - instruments taken in first difference in columns (4) and (5); in column (3): foreign demand for the core (HS4) product exported by the firm ( F D it core in the main text).

conditions, addresses this issue.

Columns (4) and (5) in Table 4 report the estimation results of the relationship between domestic and foreign sales, when all variables are expressed in first differences. Both estimations include sector $\times$ year dummies, and estimation (5) also contains firm fixed effects. These alternative specifications confirm that an increase in export sales, consecutive to an improvement in foreign demand conditions, raises domestic sales. Overall, results from columns (1) to (5) suggest that a $10 \%$ exogenous increase in exports generates between 1.5 and $3.5 \%$ increase in domestic sales. Importantly, we control for the domestic counterpart of our instruments in all estimations, and these controls are highly significant. The effect of exports on domestic 
sales that we identify can therefore hardly be attributed to common shocks affecting domestic and foreign sales simultaneously, rather represents the effect of shocks that are specific to the foreign market. We provide more robustness checks on this issue in the next subsections. ${ }^{10}$

\subsection{Robustness checks}

Business cycle correlation. Despite the fact that we explicitly control for firm-specific domestic business cycle in all specifications, one could still argue that our results may come from international business cycles correlation, and that our controls do not fully capture it. If this was the case, we should expect the complementarity between exports and domestic sales to be higher for firms exporting to countries in which business cycles are more synchronized with the French one. This would be the case, for instance, for French firms mainly exporting to EU destinations.

Columns (1) and (2) of Table 5 presents estimates which control explicitly for these phenomena. We estimate the specification of column (2), Table 4 on two different samples, which contain the firms exporting more or less inside the EU (i.e. firms for which the share of exports inside EU-15 is above or below the median of the sample), respectively: if the correlation between foreign and domestic business cycles was driving our results, the coefficient on exports should be higher for firms more exposed to the EU market.

Our results are robust, whatever the sample considered. The positive effect of exports on domestic sales is found to be significantly higher for firms exporting more outside EU-15, suggesting that business cycle correlation is unlikely to bias our results.

Export diversification. One could argue that our results are partly driven by some firms that rely heavily on sales in a particular destination. On the other hand, more diversified exporters may be less affected by a shock in foreign markets. Columns (3) and (4) in Table 5 show that our results hold for all categories of exporters, even the more diversified ones.

In columns (3) and (4) our sample is split according to the average number of destinations reached by the firm over the period. The coefficient on export sales, although significant at the $1 \%$ level in all specification, appears to be slightly higher for the most diversified firms (column

\footnotetext{
${ }^{10}$ Note also that these results are unchanged when we perform 3SLS estimations, estimating jointly the effect of foreign sales on domestic ones and the effect of domestic sales on exports. The export-domestic sales relationship is found to work both ways, but using this estimator does not affect our conclusions. This suggests that residuals correlation between the export sales and the domestic sales equations, if any, is not sufficient to significantly impact our results. These results are available upon request.
} 
Table 5: Export and domestic sales: Robustness

\begin{tabular}{lcccc}
\hline \hline & $(1)$ & $(2)$ & $(3)$ & $(4)$ \\
Estimator & \multicolumn{4}{c}{ 2SLS } \\
$\begin{array}{l}\text { Split } \\
\text { Sample }\end{array}$ & Low & High & Low & High \\
& & ln domestic sales \\
Dep. Var. & & & \\
\hline & & & \\
ln Export sales $i t$ & $0.199^{a}$ & $0.129^{a}$ & $0.152^{a}$ & $0.177^{a}$ \\
& $(0.044)$ & $(0.033)$ & $(0.041)$ & $(0.033)$ \\
& & & & \\
ln Domestic demand & & & \\
& $0.105^{a}$ & $0.104^{a}$ & $0.087^{a}$ & $0.118^{a}$ \\
& $(0.036)$ & $(0.016)$ & $(0.020)$ & $(0.029)$ \\
Observations & & & & \\
Sector $\times$ year dummies & Yes & Yes & Yes & Yes \\
Kleibergen-Paap stat. & 65.5 & 65.1 & 42.4 & 118.1 \\
\hline \hline
\end{tabular}

Robust Standard errors, clustered by NACE 36 industry, in parentheses. ${ }^{c}$ significant at $10 \%{ }^{b}{ }^{b i g n i f i c a n t}$ at $5 \%$; ${ }^{a}$ significant at $1 \%$. All estimations include firm fixed effects. The critical value for the weak instruments test is based on a $10 \% 2 \mathrm{SLS}$ bias at the $5 \%$ significance level, which is 16.4 is all estimations. The instrument in all specifications is foreign demand in HS6 products exported by the firm ( $F D_{i t}$ in the main text). High / low: higher / lower than sample median.

4). This may be due to the fact that these firms have, on average, a larger share of exports in their total sales. But overall, our results are not driven by firms whose exports are concentrated in a single market. ${ }^{11}$

Alternative instruments. A more direct way to assess the reliability of our empirical methodology is to use additional instruments to test for over-identifying restrictions. We construct two sets of alternative instruments.

First, we compute firm-specific tariffs, based on the range of product and destinations of the firms. This alternative instrument is computed exactly in the same way as $F D_{i t}$ in equation (2), but instead uses the multilateral (MFN) tariffs of destination $j$ for (HS6) product $p$ instead of imports. ${ }^{12}$ All instruments are described in full detail in the data appendix. This instrument is arguably more exogenous, but also weaker as tariff changes over the period are small. Second, we compute variables reflecting the firm's exposure to civil wars in its destination countries. We define two variables: (i) a dummy variable that equals 1 if at least one of the destinations to which the firm exported in $t-1$ experiences a civil war in year $t$; and (ii) a variable that equals the number of civil wars in the destinations served by the firm, weighted by the share

\footnotetext{
${ }^{11}$ This is also confirmed when we split the sample according to measure of geographical concentration (e.g. Herfindahl index) of exports at the firm level.

${ }^{12}$ Similar results are obtained with bound tariffs.
} 
of exports in these destinations in $t-1$.

Table 6: Instrumentation: robustness

\begin{tabular}{|c|c|c|c|c|c|c|}
\hline Estimator & $\overline{(1)}$ & $(2)$ & $\begin{array}{c}(3) \\
\text { 2SLS }\end{array}$ & (4) & $(5)$ & 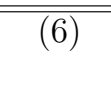 \\
\hline Dep. Var. & \multicolumn{6}{|c|}{ ln domestic sales } \\
\hline ln Export sales $i t$ & $\begin{array}{c}0.176^{a} \\
(0.032)\end{array}$ & $\begin{array}{c}0.167^{a} \\
(0.027)\end{array}$ & $\begin{array}{c}0.225^{b} \\
(0.112)\end{array}$ & $\begin{array}{c}0.237^{b} \\
(0.110)\end{array}$ & $\begin{array}{c}0.138^{b} \\
(0.057)\end{array}$ & $\begin{array}{c}0.134^{b} \\
(0.055)\end{array}$ \\
\hline ln Domestic demand $i t$ & $\begin{array}{c}0.112^{a} \\
(0.025)\end{array}$ & $\begin{array}{c}0.103^{a} \\
(0.019)\end{array}$ & & $\begin{array}{c}0.114^{a} \\
(0.030)\end{array}$ & & $\begin{array}{c}0.110^{a} \\
(0.021)\end{array}$ \\
\hline Observations & 122355 & 116344 & 89302 & 89302 & 116344 & 116344 \\
\hline Sector $\times$ year dummies & Yes & Yes & Yes & Yes & Yes & Yes \\
\hline Instruments & $F D_{i t}+$ Tariffs & $F D_{i t}+\mathrm{CW}$ & \multicolumn{2}{|c|}{ Tariffs } & \multicolumn{2}{|c|}{ Civil War } \\
\hline Hansen P-value & 0.86 & 0.83 & 0.35 & 0.32 & 0.92 & 0.91 \\
\hline Kleibergen-Paap stat. & 55.9 & 54.0 & 3.8 & 4.0 & 17.7 & 17.9 \\
\hline
\end{tabular}

Robust Standard errors, clustered by NACE 36 industry, in parentheses. ${ }^{c}$ significant at $10 \% ;{ }^{b}$ significant at $5 \%$; ${ }^{a}$ significant at $1 \%$. All estimations include firm fixed effects. The critical value for the weak instruments test is based on a $10 \% 2 \mathrm{SLS}$ bias at the $5 \%$ significance level, which is 19.9 in all estimations. See main text and appendix for a more detailed description of the instruments.

Table 6 contains the results. In addition to our baseline instrument, tariffs (column (1)) and exposure to civil war (column (2)) are used as additional instruments for exports. The Hansen tests of overidentifying restrictions cannot reject the exogeneity of our instruments in both cases. At all events, the coefficients of exports are largely unaffected. Note that the number of observations is lower because we removed from the sample the firms that export to countries in which there is no tariff variation over the period (this includes in particular EU countries) or for which information on the occurrence of civil wars is missing.

Estimations in columns (3) to (6) use our alternative instruments alone. We include both firm-specific tariff and its lag in columns (3) and (4) to be able to assess the exogeneity of this instrument. Columns (5) and (6) contain the results using both the binary and the continuous proxies for firm-specific exposure to civil wars as instruments. In all estimations, the Hansen test does not reject the orthogonality of our instruments, and the coefficient on export sales is always positive and significant at the $5 \%$ level. The coefficients are found to be quantitatively larger than before in columns (3) and (4), but our estimates are also less precise. These results suggest that, whatever the (exogenous) shock affecting the firms' foreign sales, it has a positive effect in the short-term on domestic performance. Interestingly, the results obtained using civil wars in columns (5) and (6) are very similar to our benchmark results from Table 4: a 10\% 
increase in exports generates an additional $1.3 \%$ in domestic sales.

Note that all our instruments have the expected effect on exports, as shown in the Table 10 in the appendix, which reports the first stage coefficients. Finally, our results are unchanged when we restrict our sample to the firms that are present during the entire period (Table 11 in the appendix). Therefore, firms close to bankruptcy, which could decrease simultaneously both exports and domestic sales, do not drive our results.

Imports. Recent papers have shown that offshoring may exacerbate international business cycle correlation. ${ }^{13}$ Another potential bias may arise in our estimations if firms export and import products from the same destination. The positive effect of foreign shocks on domestic sales could in this case be partly due to better or cheaper access to foreign inputs. Our firmlevel customs data also contain information on firm-product-country specific imports, so that we can explicitly control for this. We therefore include the firms' imports as a control variable in our estimation. This variable is instrumented using the foreign supply addressed to the firm by product $\left(F S_{i t}\right)$ : foreign exports by country-product are weighted by the share of each country-product pair in each firm's imports (see data appendix for more details).

Table 7 reports the estimation results that control specifically for firms' predicted imports. Columns (1) to (4) differ in terms of the instruments used for export sales: foreign demand in the HS6 product exported by the firm (column 1), foreign demand for the core (HS4) product exported by the firm (column 2), firm-specific tariffs (column 3) or exposure to civil war (column 4). In these augmented specifications, the effect of export decreases slightly in column (1), but remains positive and significant at the $1 \%$ level in all specifications. The coefficient estimate of exports varies between 0.1 and 0.2 , quantitatively close to our baseline results.

\subsection{A quasi-natural experiment: the 1997-1998 Asian crisis}

A direct implication of our results is that negative external shocks, such as financial crises, are transmitted to domestic sales through trade. The time period for which our data is available allows us to directly assess the effect of a particular event, the 1997-1998 crisis in South East Asia, on French firms' domestic sales. Both the banking and currency crises that several Asian countries experienced generated a large negative demand shock for French firms serving these destinations.

\footnotetext{
${ }^{13}$ See Bergin et al. (209) and Burstein et al. (2008).
} 
Table 7: Robustness: imports

\begin{tabular}{|c|c|c|c|c|}
\hline & $(1)$ & $(2)$ & $(3)$ & $(4)$ \\
\hline Dep. Var. & \multicolumn{4}{|c|}{ ln domestic sales } \\
\hline ln Export sales $i t$ & $\begin{array}{c}0.102^{a} \\
(0.030)\end{array}$ & $\begin{array}{c}0.214^{a} \\
(0.042)\end{array}$ & $\begin{array}{l}0.207^{a} \\
(0.044)\end{array}$ & $\begin{array}{l}0.205^{a} \\
(0.052)\end{array}$ \\
\hline ln Imports $i t$ & $\begin{array}{l}0.065^{a} \\
(0.016)\end{array}$ & $\begin{array}{l}0.051^{a} \\
(0.016)\end{array}$ & $\begin{array}{c}0.047^{b} \\
(0.023)\end{array}$ & $\begin{array}{c}0.058^{b} \\
(0.023)\end{array}$ \\
\hline ln Domestic demand $i t$ & $\begin{array}{l}0.086^{a} \\
(0.021)\end{array}$ & & & \\
\hline ln Dom. demand main prod.it & & $\begin{array}{c}0.067^{a} \\
(0.019)\end{array}$ & $\begin{array}{c}0.076^{a} \\
(0.018)\end{array}$ & $\begin{array}{l}0.088^{a} \\
(0.020)\end{array}$ \\
\hline Observations & 136004 & 136004 & 107736 & 83181 \\
\hline Sector $\times$ year dummies & Yes & Yes & Yes & Yes \\
\hline Instruments & $F D_{i t}$ & $F D_{i t}^{\text {core }}$ & $F D_{i t}^{\text {core }}+$ Tariffs & $F D_{i t}^{c o r e}+\mathrm{CW}$ \\
\hline Hansen p-value & - & - & 0.21 & 0.46 \\
\hline Kleibergen-Paap stat. / S-Y Crit. val. (10\%) & $18.0 / 7.0$ & $17.5 / 7.0$ & $5.5 / 7.6$ & $10.4 / 7.6$ \\
\hline
\end{tabular}

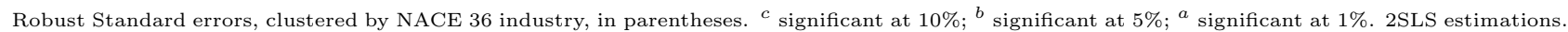
The critical values for the weak instruments test are based on a $10 \% 2 \mathrm{SLS}$ bias at the $5 \%$ significance level. The instruments are the following: in all columns, foreign supply in HS6 products imported by the firm $\left(B C_{i t}^{M}\right.$ in the main data appendix); in column (1) foreign demand in HS6 products exported by the firm $\left(F D_{i t}\right.$ in the main text); in column (2) to (4) foreign demand for the core (HS4) product exported by the firm ( $F D_{i t}^{\text {core }}$ in the main text); in column (3), firm-specific tariff; in column (4), exposure to civil wars. See appendix for more details.

Figure 1 below shows the total domestic turnover for different categories of French firms defined according to their exposure to countries that were the most affected by the crisis. Exposure is defined as the average share of total exports before the crisis (in 1995 and 1996) in the following destinations: Thailand, the Philippines, South Korea, Malaysia, and Indonesia. Panel (a) contains all the firms, while panel (b) considers the firms present in our sample over the whole 1995-2001 period. In both cases, the difference between the firms that were not exposed (i.e. did not export to these countries prior to the crisis) and the others is striking. The trend of domestic sales is either less positive for all firms with a positive exposure, or negative for firms with an exposure larger than $20 \%$.

Table 8 reports estimates of the effect of the Asian crisis on French firms' domestic sales. We regress the log of domestic sales on an interaction term between a dummy variable which identifies the years of the crisis (Asian crisis97-01, which equals 1 from 1997 on), and a dummy variable that equals 1 if the firms exported to the crisis countries before the start of the event and were consequently exposed to the shock $\left(\operatorname{exposed}_{i}\right)$. We also control for domestic demand. As already suggested by Figure 1, we find that the crisis had a significantly more negative impact 
Figure 1: Domestic turnover of French firms and exposure to the 1997-1998 Asian crisis

(a) All firms

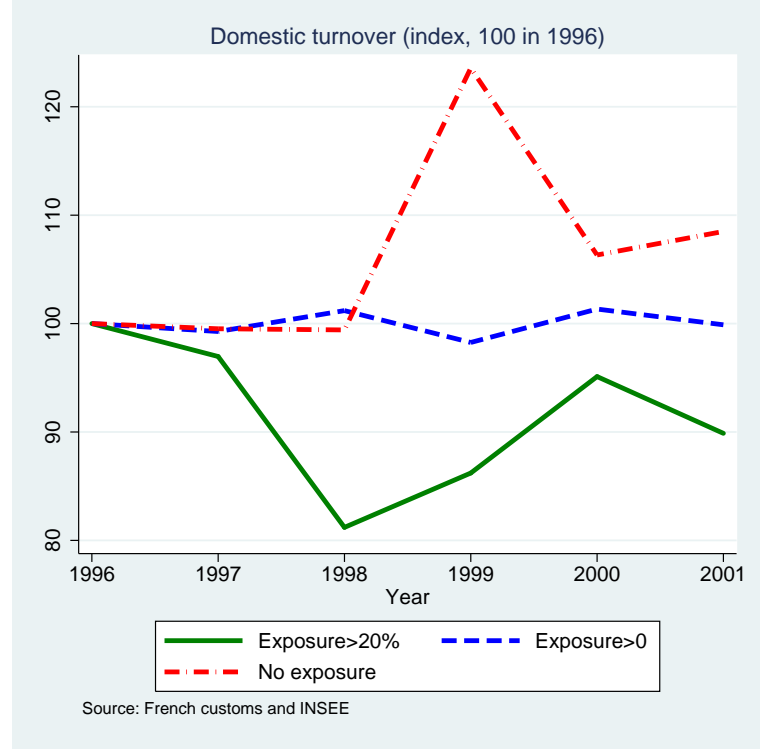

(b) Firms present all years

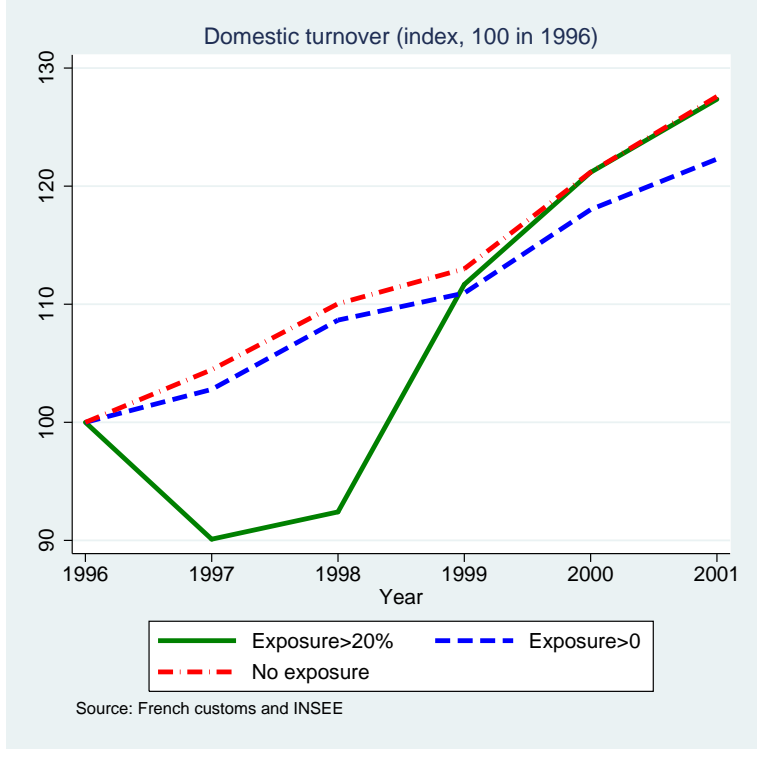

on domestic sales for firms that were exposed to the crisis countries (column 1). Domestic sales are found to be $5 \%$ lower for those firms. In column 2 , the estimation is performed on a sample of firms that are present through the entire time period of 1995-2001. Our results are robust to this alternative specification. In columns (3) and (4), the interaction term between the Asian crisis and firms' exposure before 1997 is used directly as an instrument for exports in the 2SLS estimation of the domestic sales equation $((1))$. These results confirm our previous findings: the coefficient of the exports variable is significantly positive when the Asian Crisis $97-01{ }^{*} \operatorname{Exposed}_{i}$ variable is used as instrument for exports alone (column 3) or together with firm-specific tariffs (column 4). The Hansen test indicates that we cannot reject the exogeneity of our instruments. ${ }^{14}$

\section{Channels of transmission}

How can we explain the export-domestic sales complementarity in the short run? As mentioned earlier, in most international trade models, aggregate or idiosyncratic productivity, together with local demand conditions, determines simultaneously the level of sales in each market.

\footnotetext{
${ }^{14}$ The larger coefficients on export sales in columns (3) and (4) of Table 8 may suggest that negative foreign shocks are more likely to be transmitted to domestic sales than positive ones. The symmetry of the complementarity is discussed in Appendix C. We do find that the effect of negative export variations is slightly larger than the effect of positive changes. However, the difference is statistically insignificant.
} 
Table 8: Effect of the Asian crisis on French firms domestic sales

\begin{tabular}{|c|c|c|c|c|}
\hline Sample & $\begin{array}{l}(1) \\
\text { All }\end{array}$ & $\begin{array}{c}(2) \\
\text { Firms present all years }\end{array}$ & $\begin{array}{l}(3) \\
\text { All }\end{array}$ & $\begin{array}{l}(4) \\
\text { All }\end{array}$ \\
\hline \multicolumn{5}{|l|}{ Dep. Var.: ln Domestic sales } \\
\hline Asian $_{\text {crisis }} 97-01{ }^{*}$ Exposed $_{i}$ & $\begin{array}{c}-0.036^{a} \\
(0.011)\end{array}$ & $\begin{array}{l}-0.040^{a} \\
(0.013)\end{array}$ & & \\
\hline ln Export sales_it & & & $\begin{array}{c}0.728^{b} \\
(0.325)\end{array}$ & $\begin{array}{c}0.438^{a} \\
(0.141)\end{array}$ \\
\hline ln Domestic demand ${ }_{i t}$ & $\begin{array}{c}0.142^{a} \\
(0.019)\end{array}$ & $\begin{array}{c}0.147^{a} \\
(0.019)\end{array}$ & $\begin{array}{l}-0.026 \\
(0.074)\end{array}$ & $\begin{array}{c}0.041 \\
(0.041)\end{array}$ \\
\hline Observations & 146702 & 66591 & 146702 & 122355 \\
\hline Dummies & \multicolumn{4}{|c|}{ Sector $\times$ Year } \\
\hline Estimation & $\mathrm{FE}$ & FE & $2 \mathrm{SLS}$ & 2SLS \\
\hline Instruments & & & Crisis & Crisis + Tariffs \\
\hline Hansen p-value & & & & 0.44 \\
\hline Kleibergen-Paap stat. / S-Y Crit. val. (10\%) & & & $13.2 / 16.4$ & $22.9 / 19.9$ \\
\hline
\end{tabular}

Robust Standard errors, clustered by NACE 36 industry, in parentheses. ${ }^{c}$ significant at $10 \% ;^{b}$ significant at $5 \%$; ${ }^{a}$ significant at $1 \%$. OLS estimations in columns (1) and (2) and 2SLS estimations in columns (3) and (4). All estimations include firm fixed effects. Export sales instrumented by Asian crisis $_{97-01} \times$ Exposed $_{i}$ in column (3), and by Asian crisis $97-01 \times$ Exposed $_{i}$ and firm-specific tariffs in column (4). See data appendix for more details.

Exogenous changes in demand conditions in a given market have no effect on the level of sales in other markets. However, several factors may explain why we observe a positive impact of exports on domestic sales. Before turning to these, first note that we are looking at contemporaneous effects. In the medium- to long-term, a rise in exports may increase the scale of domestic production through efficiency gains - the so-called learning-by-exporting hypothesis ${ }^{15}$. However, in the short-run, this is unlikely to explain our findings. In this section, we provide a discussion of the potential channels through which exports may affect domestic sales. In general, we will observe a positive reaction of domestic sales following a positive shock on exports if the firm's marginal costs are downward sloping. This may be due to a number of reasons.

\subsection{Liquidity}

In the short-term, firms need liquidity to fulfill working capital requirements. That is, any firm needs liquidity to purchase capital, buy intermediates, or hire additional workers so as to increase their sales in a market. In the presence of financial constraints, this requires using

\footnotetext{
${ }^{15}$ See Wagner (2007) for a survey, and the studies by Bernard and Jensen (1999), De Loecker (2007) and Park et al. (2010).
} 
internal liquidity rather than external borrowing ${ }^{16}$ (Hubbard, 1998). Short-term cash flow generated by foreign sales is therefore important to finance domestic operations.

As the dependence on short-term cash flow may be especially important for small firms, we should expect the export-domestic sales complementarity to decrease with firm size. Figures 2.a and 2.b show that, indeed, the magnitude of the effect is heterogeneous across firms. More precisely, we plot the effect of exogenous changes in exports on domestic sales for four different groups of firms, which are defined according to their average size, together with $90 \%$ confidence intervals. Size is proxied by the number of employees (figure 2.a) or value added (figure 2.b). These figures replicate estimation (3) of Table 4 on samples defined according these four quartiles of size.

Figure 2: Domestic turnover and exports variations, by quartiles of size

(a) By \# employees

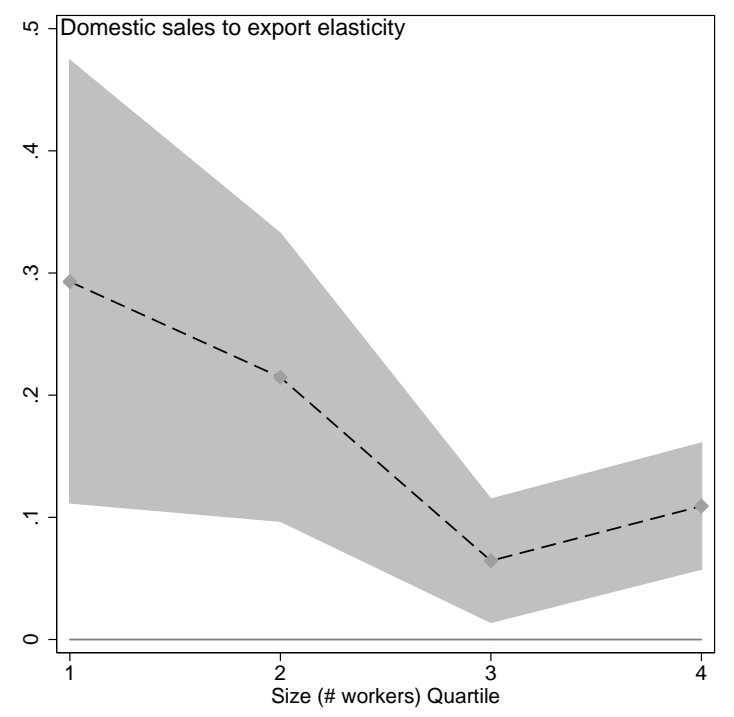

(b) By value added

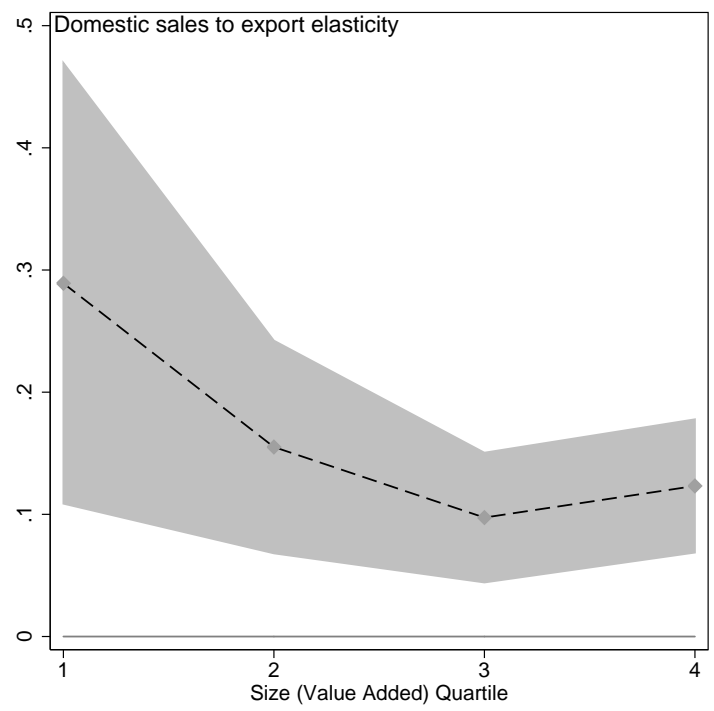

Domestic sales of firms belonging to the first quartile are found to react significantly more to changes in exports than the rest of the sample. The effect is divided by three when we move from the first to the fourth size quartile. This pattern holds regardless of whether the number of employees or value added is used as a proxy for firm size. Hence, for smaller firms, domestic performance is more related to changes in exports.

A more direct way to assess the relevance of the liquidity mechanism is to use sectoral hetero-

\footnotetext{
${ }^{16}$ In the case of capital, Berthou and Hugot (2011) use a survey of French firms in 2008 to show that among exporters, $52 \%$ of the productive investment is self-financed.
} 
geneity in terms of dependence upon short-run liquidity. More precisely, we follow a methodology akin to Rajan and Zingales (1998) and construct a sector-specific indicator of short-run needs for working capital. For each firm, our data contains the working capital requirement, computed by the INSEE. For each sector, the working capital requirement ratio (WCR/CF) is computed as the average working capital requirement divided by the average cash flow of the sector. A sector is either defined at the 2-digit (NES 36) or 3-digit (NES 114) level. This indicator represents the need of the sector in terms of short-run liquidity; a high value of WCR implies that firms in the considered sector have a higher need for short-term liquidity. Heterogeneity across sectors in terms of WCR can be explained by differences in the production or distribution processes, which can affect the frequency of earnings and payments.

Columns (1) and (2) of Table 9 show the effect of exports on domestic sales for two different samples, which are characterized by either a high (above median) or low (below median) working capital requirement ratio. The difference is striking: a 10\% exogenous increase in foreign sales generates around $2.1 \%$ increase in sales at home in the first sample, but only $0.9 \%$ in the second one. The difference is significant at the $5 \%$ level.

Figure 3 shows the size of the effect for four groups of firms defined according to the quartile of our ratio. Panel (a) uses a 2-digit sector classification, and panel (b) uses a 3-digit one. The pattern is clear: the higher the need for short-run liquidity, the higher the effect of exogenous changes in exports on domestic sales. In panel (b), this effect more than triples when we move from the first to the last quartile.

Columns (3) to (6) of Table 9 perform a similar exercise with more standard indicators of financial vulnerability, namely the sectoral asset tangibility and external financial dependence. A typology of financially vulnerable sectors has been provided in earlier works (Rajan and Zingales, 1998 and Braun, 2003): firms operating in sectors with fewer tangible and a larger dependence upon external finance are more likely to be affected by financial constraints. Columns (3) and (4) of Table 9 split the sectors according to asset tangibility; columns (5) and (6) use external financial dependence as an alternative criterion. Sectoral data for external dependence and asset tangibility comes from Braun (2003). The difference across sectors is in line with expectations, but is only statistically significant for asset tangibility. This was to be expected as these indicators are proxies for financial constraints but do not specifically focus on short-run liquidity needs. 
Table 9: Channels of transmission
(1)
(2)
(3)
(4)
(5)
(6)
(7)
(8)
(9)
(10)

Dep. Var.

In Domestic sales

\begin{tabular}{|c|c|c|c|c|c|c|c|c|c|c|}
\hline \multirow[t]{2}{*}{ Sample } & \multicolumn{2}{|c|}{$\mathrm{WCR} / \mathrm{CF}$} & \multicolumn{2}{|c|}{ Asset tangibility } & \multicolumn{2}{|c|}{ Financial dep. } & \multicolumn{2}{|c|}{ Returns to scale } & \multicolumn{2}{|c|}{ Stocks/Sales } \\
\hline & High & Low & High & Low & High & Low & Incr. & Decr. & High & Low \\
\hline ln Export sales $i t$ & $\begin{array}{c}0.214^{a} \\
(0.051)\end{array}$ & $\begin{array}{c}0.096^{a} \\
(0.031)\end{array}$ & $\begin{array}{c}0.091^{a} \\
(0.029)\end{array}$ & $\begin{array}{c}0.264^{a} \\
(0.057)\end{array}$ & $\begin{array}{c}0.203^{a} \\
(0.052)\end{array}$ & $\begin{array}{c}0.143^{a} \\
(0.045)\end{array}$ & $\begin{array}{l}0.174^{a} \\
(0.048)\end{array}$ & $\begin{array}{c}0.131^{a} \\
(0.032)\end{array}$ & $\begin{array}{l}0.213^{a} \\
(0.051)\end{array}$ & $\begin{array}{c}0.103^{b} \\
(0.040)\end{array}$ \\
\hline ln Domestic demand Dit & $\begin{array}{c}0.100^{a} \\
(0.030)\end{array}$ & $\begin{array}{c}0.089^{a} \\
(0.025)\end{array}$ & $\begin{array}{c}0.142^{a} \\
(0.024)\end{array}$ & $\begin{array}{c}0.085^{a} \\
(0.031)\end{array}$ & $\begin{array}{c}0.099^{a} \\
(0.025)\end{array}$ & $\begin{array}{c}0.102^{a} \\
(0.038)\end{array}$ & $\begin{array}{c}0.086^{a} \\
(0.029)\end{array}$ & $\begin{array}{c}0.110^{a} \\
(0.028)\end{array}$ & $\begin{array}{c}0.094^{a} \\
(0.029)\end{array}$ & $\begin{array}{c}0.094^{a} \\
(0.030)\end{array}$ \\
\hline Difference in coefficients & \multicolumn{2}{|c|}{$\begin{array}{c}0.118^{b} \\
(0.059)\end{array}$} & \multicolumn{2}{|c|}{$\begin{array}{c}-0.173^{b} \\
(0.064)\end{array}$} & \multicolumn{2}{|c|}{$\begin{array}{c}0.060 \\
(0.068)\end{array}$} & \multicolumn{2}{|c|}{$\begin{array}{c}0.043 \\
(0.032)\end{array}$} & \multicolumn{2}{|c|}{$\begin{array}{c}0.110^{b} \\
(0.060)\end{array}$} \\
\hline Observations & 72976 & 63028 & 69915 & 51882 & 54463 & 59719 & 79249 & 56755 & 71014 & 63852 \\
\hline
\end{tabular}

Robust Standard errors, clustered by NACE 36 industry, in parentheses. ${ }^{c}$ significant at $10 \%{ }^{b}$ significant at $5 \%$; ${ }^{a}$ significant at $1 \% .2$ SLS estimations. All estimations include firm fixed effects and sector $\times$ year dummies, that are defined at the same level as the sector-specific variable used for sample splitting. The instrument used for export is the foreign demand in HS6 products exported by the firm as defined in the main text. WKR/CF is the sector specific working capital requirement over cash flow ratio. Asset tangibility and external financial dependence come from Braun (2003). Stock/Sales come from Vannoorenberghe (2011).

Increasing returns. If the firm's production technology exhibits increasing returns, a positive demand shock on the foreign market will increase the production scale and decrease average cost. This increase of firm's efficiency should promote sales at home if it is - at least partially reflected in the price of goods sold in the domestic market. This mechanism will be observed if the products sold by the firm in two different markets are produced using the same inputs. For instance, increasing sales in foreign markets may help to pay the maintenance cost of production facilities, which is shared by all markets. Additional workers may also be hired in the short-run, therefore increasing the firm's supply capacity. Similar reasoning applies to the firm's capital.

Similarly, increasing returns may be related to the evolution of productivity along the business cycle. An important literature has identified the empirical fact that TFP is procyclical (see Basu and Fernald, 2001 for a survey). This pattern has been partly explained by the existence of factor hoarding along the business cycle: firms tend to adjust the rate of capital and labor utilization in periods of booms and busts, which tends to propagate shocks (Burnside et al., 1993; Burnside and Eichenbaum, 1996). For instance, Devereux (2000) shows that aggregate demand shocks lead firms to reallocate their labor, therefore affecting the skill intensity of tasks of individual workers. Firms also have the possibility of adjusting the number of hours worked 
Figure 3: Domestic turnover and exports: the role of liquidity

(a) 2-digit sector class.



(b) 3-digit sector class.

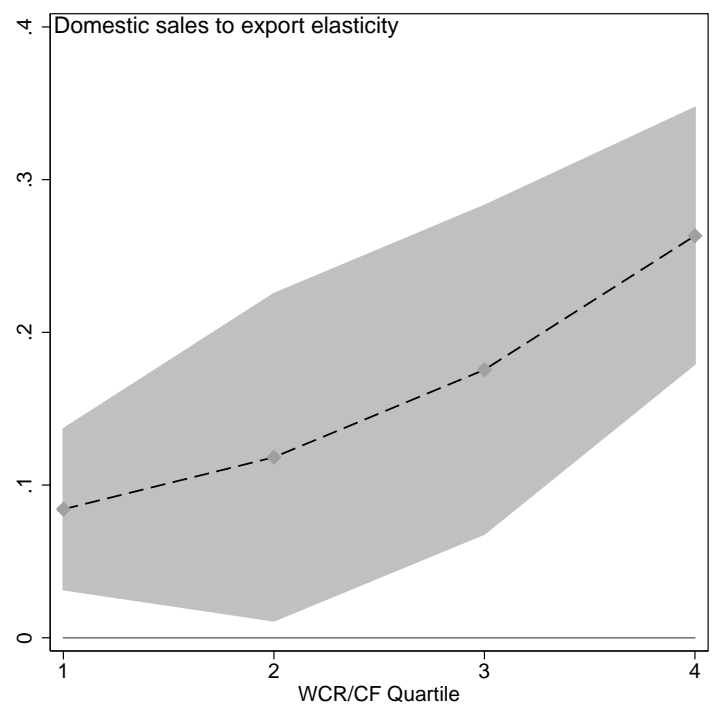

per employee. Accordingly, positive shocks on aggregate demand in one market are expected to increase factor utilization within the firm, its efficiency, and therefore its capacity to sell goods in the other markets. This channel is directly related to the firm's production capacities at the time of the shock. Additionally, it implies that the complementarity between sales in different markets mainly come from adjustments in the firm's TFP (or factor utilization), not from factor accumulation. The results shown in Table 13 in the appendix are inconsistent with this: both TFP and factor accumulation seems to be affected by foreign shocks through exports.

More generally, the IRS story can be tested by looking at the differences across sectors in terms of economies of scale. Namely, we estimate a production function by 2-digit sector (NES 114). Whenever the sum of the labor and capital coefficients is larger than 1, we classify the sector as an increasing returns sector (decreasing returns otherwise). The results, shown in columns (7) and (8) of Table 9, are consistent with our intuition: in this case, exports have a slightly more positive impact on domestic sales in the sectors that exhibit increasing returns. However, the coefficient on exports is positive and significant at the $1 \%$ level in both sub-samples, and the difference across samples is insignificant. Moreover, firms in our sample exhibit constant returns to scale on average. This channel is therefore unlikely to fully explain our results. 
Capacity constraints. As mentioned in the introduction, a number of recent papers (Vannoorenberghe, 2011, Nguyen and Schaur, 2011, Soderby, 2011, Blum et al., 2011) emphasize the fact that the presence of capacity constraints or convex costs may generate substitutability between sales across destinations. While our results suggest that domestic and foreign sales are complementary, and therefore that other channels are more prevalent ${ }^{17}$, we should expect the complementarity between sales across markets to be stronger in firms facing low capacity constraints. We test this prediction using sector-specific data on average stock over sales ratio from Vannoorenberghe (2011). ${ }^{18}$

Columns (9) and (10) show the estimates of the effect of export sales on domestic sales for firms belonging to sectors in which inventories are either high (above the sample median, in column (9)) or low (below the sample median, in column (10)). The results are consistent with Vannoorenberghe (2011): in sectors where inventories are large, i.e., where firms are less likely to face capacity constraints, the complementarity is stronger. However, the coefficient on export sales remains positive and significant in both estimations.

\section{Conclusions}

Using a large firm-level database on French firms combining balance-sheet and destinationspecific export information over the period 1995-2001, this paper shows that firms' domestic and export sales are complementary when exports are predicted by exogenous changes in foreign demand. This result differs from the apparent negative correlation between the two variables. A change in foreign macroeconomic conditions, which is associated with an increase in the foreign demand of the products sold abroad by the exporter, raises domestic sales. This implies that shocks on foreign markets can be channeled into the domestic business cycle through the complementarity between firms' domestic and foreign sales.

These results are confirmed by a number of robustness checks, in which we assess the validity of the empirical analysis through different specifications. We use alternatively as instruments for export sales the the foreign imports for the product range exported by the firm, or for its

\footnotetext{
${ }^{17}$ Note that our findings are not inconsistent with the main results of Vannoorenberghe, 2011 or Nguyen and Schaur, 2011, i.e. that that exporting increases domestic and global sales volatility. Intuitively, it is the existence of a correlation between sales across markets, rather than the sign of this correlation, that can generate more volatility.

${ }^{18}$ We are very grateful to Gonzague Vannoorenberghe who accepted to share this data. The index is computed from Amadeus data on French firms over the period 1998-2007. For more information see Vannoorenberghe (2011).
} 
core product, tariff changes, or large foreign shocks such as civil wars. We take into account the possibility that domestic and foreign macroeconomic conditions may be correlated. We also control for the possibility that the result might be driven by the correlation between exports and imports for each firm. Our results are valid in cases where the foreign demand for firms' products is increasing or decreasing. Finally, our analysis is supported by the natural experiment of the Asian crisis in the late 1990's. Estimation results show that firms that were more exposed to this crisis through their exports suffered a decrease of their domestic sales as compared to firms of the control group.

Overall, this relation between domestic and foreign sales is at odds with theoretical models in international trade where domestic and foreign sales are only connected through exogenous productivity, as in Melitz (2003). Our results rather suggest that exogenous shocks on the foreign business cycle will reflect in the domestic business cycle through the relationship between domestic and foreign sales. This result has many implications, for instance, in terms of the exchange rate policy or trade policy transmission to the domestic economy.

The precise channel of transmission, however, remains an avenue for future research. We provide evidence in the last section that dependence on short-run liquidity, through working capital requirement, may be a relevant explanation. This channel is also consistent with the fact that our result is found to be stronger for small firms than for large ones. However, other channels may be relevant, including demand side mechanisms. If the firms' marginal revenue is upward sloping, one should expect a positive relationship between foreign and domestic sales. This may be the case if French firms that serve the same foreign markets (and therefore facing the same demand shocks) interact with each other on the domestic market, through trade in inputs. For instance, assume that two French firms are both selling to Germany the same final good, and sell to each other the inputs involved in the production of this good. When demand increases in Germany, firms will expand their domestic sales as input demand will increase at home. This channel should be observed in particular in sectors in which the firms interact with each other more intensely along the supply chain. Future research should probably attempt to determine the channel of transmission that is prevalent in explaining this export-domestic sales complementarity. 


\section{References}

Ball, R. J., Eaton, J. R. and Steuer, M. D. (1966), "The Relationship Between United Kingdom Export Performance in Manufactures and the Internal Pressure of Demand", The Economic Journal, vol. $76 \mathrm{n}^{\circ} 303$.

Basu, S. and Fernald, J. (2001), "Why Is Productivity Procyclical? Why Do We Care?", in New Developments in Productivity Analysis, National Bureau of Economic Research, Inc, NBER Chapters, pp. 225-302.

Baxter, M. and Kouparitsas, M. A. (2005), "Determinants of business cycle comovement: a robust analysis", Journal of Monetary Economics, vol. 52 n 1: pp. 113-157.

Bergin, P., Feenstra, R. and Hanson, G. (209), "Volatility due to Outsourcing: Theory and Evidence", Mimeo.

Bernard, A. and Jensen, B. (1999), "Exceptional exporter performance: cause, effect, or both?", Journal of International Economics, vol. 47 no 1: pp. 1-25.

Bernard, A. and Wagner, J. (1998), "Export Entry and Exit by German Firms", NBER Working Paper W6538.

Berthou, A. and Hugot, J. (2011), "How does innovation affects the internationalization patterns of firms?", EFIGE country report France.

Blum, B. S., Claro, S. and Horstmann, I. J. (2011), "Occasional vs Perennial Exporters: The Impact of Capacity on Export Mode", .

Braun, M. (2003), "Financial Contractibility and Asset Hardness", Harvard University, Department of Economics Working Paper.

Burnside, C. and Eichenbaum, M. (1996), "Factor-Hoarding and the Propagation of Business-Cycle Shocks", American Economic Review, vol. 86 n 5: pp. 1154-74.

Burnside, C., Eichenbaum, M. and Rebelo, S. (1993), "Labor Hoarding and the Business Cycle", Journal of Political Economy, vol. 101 no 2: pp. 245-73. 
Burstein, A., Kurz, C. and Tesar, L. (2008), "Trade, production sharing, and the international transmission of business cycles", Journal of Monetary Economics, vol. $55 \mathrm{n}^{\circ}$ 4: pp. $775-795$.

De Loecker, J. (2007), "Do exports generate higher productivity? Evidence from Slovenia", Journal of International Economics, vol. 73 n 1: pp. 69-98.

Devereux, P. J. (2000), "Task Assignment over the Business Cycle", Journal of Labor Economics, vol. $18 \mathrm{n}^{\mathrm{o}}$ 1: pp. 98-124.

Dunlevy, J. A. (1980), “A Test of the Capacity Pressure Hypothesis within a Simultaneous Equations Model of Export Performance", The Review of Economics and Statistics, vol. 62 $\mathrm{n}^{\mathrm{o}}$ 1: pp. 131-35.

Eaton, J., Kortum, S. and Kramarz, F. (2004), "Dissecting Trade: Firms, Industries, and Export Destinations", American Economic Review Papers and Proceedings, vol. 94 n 2: pp. $150-154$.

Eaton, J., Kortum, S. and Kramarz, F. (2011), "An Anatomy of International Trade: Evidence from French Firms", Econometrica, vol. Forthcoming.

Ekholm, K., Moxnes, A. and Ulltveit-Moe, K.-H. (2011), "Manufacturing restructuring and the role of Real exchange rate shocks: A firm level analysis", Journal of International Economics, vol. Forthcoming.

Frankel, J. A. and Rose, A. K. (1998), "The Endogeneity of the Optimum Currency Area Criteria", Economic Journal, vol. 108 n 449: pp. 1009-25.

Froot, K. A. (1989), "Consistent covariance matrix estimation with cross-sectional dependence and heteroskedasticity in financial data", Journal of Financial and Quantitative Analysis, vol. 24: pp. 333-335.

Haynes, S. E. and Stone, J. A. (1983), "Secular and Cyclical Responses of U.S. Trade to Income: An Evaluation of Traditional Models", The Review of Economics and Statistics, vol. $65 \mathrm{n}^{\circ}$ 1: pp. $87-95$.

HubBard, G. (1998), "Capital Market Imperfections and Investment", Journal of Economic Literature, vol. 36 n 3: pp. 193-225. 
Hummels, D., Jorgensen, R., Munch, J. and Xiang, C. (2010), "The Wage and Employment Effects of Outsourcing: Evidence from Danish Matched Worker-Firm Data", Mimeo.

Melitz, M. (2003), "The Impact of Trade on Intra-Industry Reallocations and Aggregate Industry Productivity", Econometrica, vol. 71 no 6: pp. 1695-1725.

Nguyen, D. and Schaur, G. (2011), "Cost linkages transmit volatility across markets", Mimeo.

Park, A., YAng, D., Shi, X. and Jiang, Y. (2009), "Exporting and Firm Performance: Chinese Exporters and the Asian Financial Crisis", Nber working papers, National Bureau of Economic Research, Inc.

PArk, A., YAng, D., Shi, X. and JiAng, Y. (2010), "Exporting and Firm Performance: Chinese Exporters and the Asian Financial Crisis", The Review of Economics and Statistics, vol. $92 \mathrm{n}^{\mathrm{o}}$ 4: pp. $822-842$.

Rajan, R. G. and Zingales, L. (1998), "Financial Dependence and Growth", American Economic Review, vol. 88 n 3: pp. 559-86.

Soderby, A. (2011), "Market size, Structure, and Access: Capacity constraints and trade", Mimeo.

Stock, J. H. and Yogo, M. (2005), "Testing for Weak Instruments in Linear IV Regression", in Andrews, D. W. and Stock, J. H. (editors), Identification and Inference for Econometric Models: Essays in Honor of Thomas Rothenberg, Cambridge: Cambridge University Press.

VAn Biesebroeck, J. (2005), "Exporting raises productivity in sub-Saharan African manufacturing firms", Journal of International Economics, vol. 67 no 2: pp. 373-391.

VAnnoorenberghe, G. (2011), "Firm volatility and exports", Forthcoming Journal of International Economics.

Wagner, J. (2007), "Exports and Productivity: A Survey of the Evidence from Firm-level Data", The World Economy, vol. 30 n 1: pp. 60-82. 
Zilberfarb, B.-Z. (1980), "Domestic Demand Pressure, Relative Prices and the Exports Supply Equation-More Empirical Evidence", Economica, vol. 47 n ${ }^{\circ}$ 188: pp. 443-50. 


\section{A Instruments: first stages}

Table 10: First stage estimations

\begin{tabular}{|c|c|c|c|c|c|}
\hline \multirow[b]{2}{*}{ Dep. Var. } & $\overline{(1)}$ & 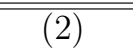 & $\begin{array}{l}(3) \\
\end{array}$ & $\overline{~(4)}$ & 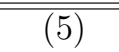 \\
\hline & \multicolumn{5}{|c|}{ ln export sales } \\
\hline \multicolumn{6}{|l|}{ Instruments } \\
\hline$F D_{i t}$ & $\begin{array}{c}0.372^{a} \\
(0.038)\end{array}$ & & & & \\
\hline$F D_{i t}^{\text {core }}$ & & $\begin{array}{l}0.239^{a} \\
(0.041)\end{array}$ & & & \\
\hline$\tau_{i t}^{X}$ & & & $\begin{array}{l}-0.010^{b} \\
(0.004)\end{array}$ & & \\
\hline$W a r_{i t}^{X}$ & & & & $\begin{array}{c}-0.283^{a} \\
(0.051)\end{array}$ & \\
\hline Crisis ${ }_{i t}^{X}$ & & & & & $\begin{array}{l}-0.050^{a} \\
(0.014)\end{array}$ \\
\hline$D D_{i t}$ & $\begin{array}{c}0.102^{a} \\
(0.029)\end{array}$ & & & & \\
\hline$D D_{i t}^{\text {core }}$ & & $\begin{array}{l}0.084^{a} \\
(0.018)\end{array}$ & & & \\
\hline Observations & 146702 & 146702 & 89302 & 116344 & 146702 \\
\hline
\end{tabular}

Robust Standard errors, clustered by NACE 36 industry, in parentheses. ${ }^{c}$ significant at $10 \% ;^{b}$ significant at $5 \%$; ${ }^{a}$ significant at $1 \%$. 2 SLS estimations. First stage estimates of Table 4: columns (2) and (3); Table 6: columns (3) and (5); and Table 8: column (6). All estimations include firm fixed effects and sector $\times$ year dummies. See the data appendix for more details on the computation of the instruments. 


\section{B Instruments: Robustness}

Table 11: Instrumentation: robustness (firm present in all years)

\begin{tabular}{|c|c|c|c|c|c|c|}
\hline Estimator & $(1)$ & $(2)$ & $\begin{array}{c}(3) \\
2 S L S\end{array}$ & (4) & $(5)$ & 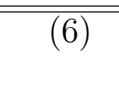 \\
\hline Dep. Var. & \multicolumn{6}{|c|}{ ln domestic sales } \\
\hline ln Export sales $i t$ & $\begin{array}{c}0.140^{a} \\
(0.037)\end{array}$ & $\begin{array}{c}0.147^{a} \\
(0.030)\end{array}$ & $\begin{array}{c}0.340^{c} \\
(0.204)\end{array}$ & $\begin{array}{c}0.356^{c} \\
(0.202)\end{array}$ & $\begin{array}{c}0.234^{b} \\
(0.095)\end{array}$ & $\begin{array}{c}0.230^{b} \\
(0.094)\end{array}$ \\
\hline ln Domestic demand $i t$ & $\begin{array}{c}0.134^{a} \\
(0.027)\end{array}$ & $\begin{array}{c}0.102^{a} \\
(0.019)\end{array}$ & & $\begin{array}{c}0.077^{c} \\
(0.043)\end{array}$ & & $\begin{array}{c}0.085^{a} \\
(0.025)\end{array}$ \\
\hline Observations & 59318 & 57078 & 50844 & 50844 & 57078 & 57078 \\
\hline Sector $\times$ year dummies & Yes & Yes & Yes & Yes & Yes & Yes \\
\hline Instruments & Base+Tariffs & Base + CW & \multicolumn{2}{|c|}{ Tariffs } & \multicolumn{2}{|c|}{ Civil War } \\
\hline Hansen P-value & 0.62 & 0.15 & 0.55 & 0.55 & 0.30 & 0.30 \\
\hline Kleibergen-Paap stat. & 64.6 & 60.2 & 2.3 & 2.5 & 5.9 & 6.1 \\
\hline
\end{tabular}

Robust Standard errors, clustered by NACE 36 industry, in parentheses. ${ }^{c}$ significant at $10 \%{ }^{b}$ significant at $5 \%$; ${ }^{a}$ significant at $1 \%$. All estimations include firm fixed effects. The critical value for the weak instruments test is based on a $10 \% 2 \mathrm{SLS}$ bias at the $5 \%$ significance level, which is 19.9 in all estimations. See the main text and data appendix for a more detailed description of the instruments. 


\section{Asymmetry}

In this section we try to determine whether our effect is symmetric, i.e., whether our results are identical for both positive and negative shocks on export sales. The positive coefficient on export sales may indeed capture the fact that domestic sales decrease when exports decrease (as it was the case during the Asian crisis, as shown Table 8), but not necessarily that increases in exports generate increases in domestic sales.

Table 12: Asymmetry

\begin{tabular}{|c|c|c|}
\hline & $(1)$ & $(2)$ \\
\hline Dep. Var.: & \multicolumn{2}{|c|}{$\Delta \ln$ Dom. sales } \\
\hline Negative $\Delta \ln$ Export sales $_{i t}$ & $\begin{array}{c}0.248^{a} \\
(0.059)\end{array}$ & \\
\hline Positive $\Delta \ln$ Export sales $_{i t}$ & $\begin{array}{c}0.220^{a} \\
(0.053)\end{array}$ & \\
\hline Low $\Delta \ln$ Export sales $_{i t}$ & & $\begin{array}{c}0.253^{a} \\
(0.067)\end{array}$ \\
\hline High $\Delta$ ln Export sales $i t$ & & $\begin{array}{c}0.240^{a} \\
(0.042)\end{array}$ \\
\hline$\Delta \ln$ Domestic demand $_{i t}$ & $\begin{array}{c}0.089^{a} \\
(0.014)\end{array}$ & $\begin{array}{c}0.086^{a} \\
(0.013)\end{array}$ \\
\hline Observations & $\begin{array}{c}110721 \\
\text { 2SLS }\end{array}$ & 110719 \\
\hline Kleibergen-Paap stat. / S-Y Crit. val. (10\%) & $18.7 / 7.0$ & $20.5 / 7.0$ \\
\hline
\end{tabular}

Robust Standard errors, clustered by NACE 36 industry, in parentheses. ${ }^{c}$ significant at $10 \%{ }^{b}{ }^{b i g n i f i c a n t}$ at $5 \%$; ${ }^{a}$ significant at $1 \%$. All estimations include firm fixed effects and sector $\times$ year dummies. Critical values for the weak instruments test are based on a $10 \% 2$ SLS bias at the $5 \%$ significance level.

We check the symmetry of the effect of exports on domestic sales using two different approaches. In both cases we use first difference estimations. First, we split the exports variable into positive and negative exports variations at the firm level. Instruments are consistently modified versions of the ones previously presented. Second, we divide exports according to whether their variations are above or below the firm-level average. Results are provided in Table (12). In both cases, the effect of negative export variations is found to be slightly larger than the effect of a positive export variation on domestic sales growth. Overall, these results confirm our previous findings that exogenous changes in exports drive domestic sales in the 
same direction. This result is observed for both positive and negative variations of exports.

\section{Factor accumulation vs. TFP gains}

The positive effect of foreign shocks on domestic sales can either be channeled through more factor accumulation or TFP variations. Whether one is more affected that the other may help us understand the precise channels of transmission. In Table 13 we estimate the effect of exogenous export variations on capital and labor (columns (2) and (3)) and on TFP ${ }^{19}$ (column (4)). Column (1) replicates our baseline results. Column (5) simply shows the result of a regression of domestic sales on capital, labor and TFP. The total effect of exports on domestic sales is the sum of the coefficients on exports from columns (2) to (4), weighted by the impact of each factor on domestic sales shown in column (5). Our results suggest that the shocks affecting export sales both affect factor accumulation and TFP, with a higher effect on TFP. Accounting for the effect of each component on the firms' domestic sales, factor accumulation and TFP variations are found to explain one and two thirds of the overall effect, respectively.

${ }^{19} \mathrm{TFP}$ is computed sector by sector using Olley and Pakes (1996) methodology. 
Table 13: Decomposition of the effect

\begin{tabular}{|c|c|c|c|c|c|}
\hline & (1) & (2) & & 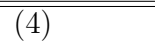 & (5) \\
\hline $\begin{array}{l}\text { Estimator } \\
\text { Dep. var. }\end{array}$ & $\begin{array}{l}\ln \text { Dom. } \\
\text { Sales }\end{array}$ & $\begin{array}{l}\text { ln \# Work- } \\
\text { ers }\end{array}$ & $\begin{array}{c}\text { 2SLS } \\
\text { ln K stock }\end{array}$ & $\ln \mathrm{TFP}$ & $\begin{array}{l}\ln \text { Dom. } \\
\text { Sales }\end{array}$ \\
\hline ln Export sales $i t$ & $\begin{array}{l}0.158^{a} \\
(0.029)\end{array}$ & $\begin{array}{l}0.129^{a} \\
(0.022)\end{array}$ & $\begin{array}{l}0.148^{a} \\
(0.024)\end{array}$ & $\begin{array}{l}0.212^{a} \\
(0.027)\end{array}$ & \\
\hline ln Domestic demand $i t$ & $\begin{array}{l}0.105^{a} \\
(0.021)\end{array}$ & $\begin{array}{l}0.013 \\
(0.017)\end{array}$ & $\begin{array}{l}0.020 \\
(0.017)\end{array}$ & $\begin{array}{l}0.095^{a} \\
(0.018)\end{array}$ & \\
\hline $\ln \#$ workers $_{i t}$ & & & & & $\begin{array}{l}0.664^{a} \\
(0.026)\end{array}$ \\
\hline $\ln \mathrm{K}$ stock $_{i t}$ & & & & & $\begin{array}{l}0.189^{a} \\
(0.012)\end{array}$ \\
\hline $\ln \mathrm{TFP}_{i t}$ & & & & & $\begin{array}{l}0.753^{a} \\
(0.031)\end{array}$ \\
\hline Observations & 146702 & 146702 & 146702 & 146702 & 146702 \\
\hline Estimation & 2SLS & 2SLS & 2SLS & 2SLS & $\mathrm{FE}$ \\
\hline Kleibergen-Paap stat. / S-Y Crit. val. (10\%) & $94.9 / 16.4$ & $94.9 / 16.4$ & $94.9 / 16.4$ & $94.9 / 16.4$ & - \\
\hline
\end{tabular}

Robust Standard errors, clustered by NACE 36 industry, in parentheses. ${ }^{c}$ significant at $10 \% ;{ }^{b}$ significant at $5 \%$; ${ }^{a}$ significant at $1 \%$. All estimations include firm fixed effects and sector $\times$ year dummies. Critical values for the weak instruments test are based on a $10 \% 2 \mathrm{SLS}$ bias at the $5 \%$ significance level. Weights are computed using the firm's average share of exports in total turnover of the firm in year $t$. The instrument is the foreign demand in HS6 products exported by the firm and in sector $k$.

\section{E Data Appendix}

The sample is made of yearly firm-level data over the period 1995-2001. Indexes $i, j, k, p$ and $t$ represent the firm, the destination served, the sector the firm belongs to, the product exported and the time unit (year), respectively. We provide a complete description of the variables below:

\section{E.1 Main interest variables}

Foreign and Domestic sales $\left(X_{i t}\right.$ and $\left.Y_{i t}\right)$. The BRN contains direct information on total sales and export sales. Domestic sales are therefore computed as the difference between total and export sales.

TFP. TFP is computed using the Olley and Pakes (1996) methodology and is estimated sector by sector (NES 36 classification), therefore allowing for different input coefficients across sectors. Capital is deflated using a gross fixed asset deflator from the OECD economic outlook database and value added using a sectoral deflator from the EU-Klems data.

Inputs. Capital stock and the number of employees are from the BRN. Firm specific imports, 
by product and destination, are taken the French customs.

\section{E.2 Instruments and controls for domestic demand}

Foreign and domestic demands addressed to the firms. Our preferred instrument is the sum of foreign imports in the product-destination served by the firm in year $t$, weighted by the share of each product-destination in the firm's total export over the period. A product is defined at the 6-digit (HS6) level. Import data comes from BACI (CEPII). Denoting $\omega_{i j p}$ the average share of each product $p$ and destination $j$ in firm $i$ 's exports over the period, and $M_{j p, t}$ the imports of destination $j$ of product $p$ during year $t$, this variable is computed as:

$$
F D_{i t}=\sum_{j, p} \omega_{i j p} M_{j p, t}
$$

The mirror of this variable for domestic demand is:

$$
D D_{i t}=\sum_{j, p} \omega_{i j p} M_{F R, p, t}
$$

where $M_{F R, p, t}$ denotes the French imports of product $p$ during year $t$. Alternatively, we use similar instruments and controls focusing on the firm's core product, defined as the HS4 product with the highest average value of exports over the period. $\omega_{i j}^{\text {core }}$ is the weight of destination $j$ in firm's $i$ core product exports. We compute:

$$
F D_{i t}^{c o r e}=\sum_{j} \omega_{i j}^{\text {core }} M_{j, t}^{\text {core }}
$$

And:

$$
D D_{i t}^{\text {core }}=\sum_{j} \omega_{i j}^{\text {core }} M_{F R, t}^{\text {core }}
$$

Firm-specific tariffs. We use information on tariff to construct alternative instruments for export sales. Firm-specific tariffs are computed as:

$$
\tau_{i t}^{X}=\sum_{j, p} \omega_{i j p} t_{j p, t}
$$


where $t_{j p, t}$ represents the MFN tariff of destination $j$ in product $p$. The data comes from the ITC. Similar results are obtained with bound tariffs.

Exposure to civil wars. We construct two variables reflecting the exposure of a given firm $i$ to a civil war in country $j$. The first is a dummy variable that equals 1 if at least one the destinations to which the firm exported in $t-1$ experiences a civil war in year $t$. The second equals the sum of the number of civil wars the destination served by the firm, weighted by the share of exports in these destinations in $t-1$ :

$$
W a r_{i t}^{X}=\sum_{j} \frac{X_{i j, t-1}}{X_{i, t-1}} C W_{j, t}
$$

where $C W_{j, t}$ is a dummy that equals 1 if the destination $j$ experienced a civil war in $t$. The data on civil wars comes from the Correlates of War (CoW).

Instruments for imports. We create instruments for firm-level imports using a similar variable as for exports. Firms' imports are instrumented using the foreign supplied addressed to the firm, $F S_{i t}$. More precisely, we compute the sum of the foreign exports in the productdestination from which the firm imports goods during year $t, X_{j p t}$, weighted by the share of each product-destination in the firm's total imports over the period $\eta_{i j p}$. A product is defined at the 6-digit (HS6) level, $\eta_{i j p}$. Export data comes from BACI (CEPII). This variable is computed as:

$$
F S_{i t}=\sum_{j, p} \eta_{i j p} X_{j p, t}
$$

Exposure to the 1997-1998 Asian crisis. We construct a variable similar to the one proposed for civil wars:

$$
\text { Crisis }_{i t}^{X}=\sum_{j^{*}} \exp _{i t} \text { Crisis }_{j, t}
$$

where Crisis $_{j, t}$ is a dummy variable that equals 1 after 1997 for the five Asian countries that were hit the most by the Asian crisis (Thailand, Korea, Philippines, Indonesia, Malaysia) and $\exp _{i t}$ is a dummy variable that equals 1 if the firm exported to one of these countries in 1995 or 1996. 